\title{
Correspondence
}

\section{Hubbard Glacier update: another closure of Russell Fiord in the making?}

Hubbard Glacier $\left(60^{\circ} 00^{\prime} \mathrm{N}, 139^{\circ} 29^{\prime} \mathrm{W}\right)$, with an area of $3400 \mathrm{~km}^{2}$, is the largest non-polar tidewater glacier in the world. It descends over $120 \mathrm{~km}$ from its origins on the flanks of Mount Logan (5959 m a.s.l.) in Yukon, Canada, to sea level where its $11 \mathrm{~km}$ wide terminus calves icebergs into Disenchantment Bay and Russell Fiord in southeast Alaska, USA. With a total area ratio of $95 \%$, Hubbard Glacier is in the advance phase of the so-called tidewater glacier cycle (Trabant and others, 2003), advancing $620 \mathrm{~m}$ from 1992 to 2006 at an average rate of $35 \mathrm{~m} \mathrm{a}^{-1}$ (Ritchie and others, 2008). Hubbard Glacier has twice closed off Russell Fiord at its seaward entrance (Fig. 1), creating a $60 \mathrm{~km}$ long glacierdammed lake, once in 1986 and again in 2002. Both dams failed catastrophically, releasing two of the world's largest historic outburst floods (5 and $3 \mathrm{~km}^{3}$ respectively) (Motyka and Truffer, 2007). High calving rates coupled with submarine melting driven by the combination of tidal currents $\left(\sim 5 \mathrm{~m} \mathrm{~s}^{-1}\right)$, warm sea water $\left(5-11^{\circ} \mathrm{C}\right)$ and a deep channel have thus far inhibited another closure. However, rapid deposition of $\sim 3.3 \times 10^{6} \mathrm{~m}^{3}$ of glaciofluvial sediment near Gilbert Point during August 2007 has led us to examine whether a new closure may be in the making. Such a closure is of concern to local inhabitants because sustained damming of Russell Fiord will cause the lake to backflow into the Situk River, dramatically changing the landscape, creating floods, destroying fish habitats, and threatening structures. Past closures were facilitated by the terminus pushing glaciomarine sediments above tidewater at Gilbert
Point during its springtime seasonal advance. The moraine limited calving losses, which allowed the glacier to advance rapidly across the narrow channel that typically separates Gilbert Point and the ice face.

Hubbard Glacier ordinarily undergoes a 200-300 m seasonal advance-and-retreat cycle, with retreat typically beginning in mid-June (Ritchie and others, 2008). Daily range data acquired in 2007 by the US Army Cold Regions Research and Engineering Laboratory (CRREL) from a laser ranger positioned across from the ice face at Gilbert Point (Finnegan and others 2007; Fig. 2) document that the terminus approached to within $120 \mathrm{~m}$ of the point before abruptly retreating after 14 June 2007 (http://www. GlacierResearch.org). It was therefore surprising when observers from the nearby community of Yakutat reported that a new moraine had developed in mid-August, a time when the terminus was in seasonal retreat. However, an aerial photograph taken on 11 August clearly shows that the likely source of the sediment was not a push moraine but instead a large subglacial outlet stream (Fig. 1). A time-lapse camera located at the CRREL Gilbert Point site across from the terminus captured the earliest indication of this icemarginal glaciofluvial moraine on 10 August 2007. The timelapse sequence, synthetic aperture radar (SAR) images and oblique aerial photographs documented the development of an ice spur and glaciofluvial moraine near Gilbert Point during mid-August. An oblique aerial photograph taken about noon on 26 August at high tide shows the fully developed glaciofluvial fan (Fig. 3). The exposed area of the sediment fan measured about $400 \mathrm{~m}$ by $250 \mathrm{~m}$, with a narrow ice spur connecting it to the main terminus. Both features

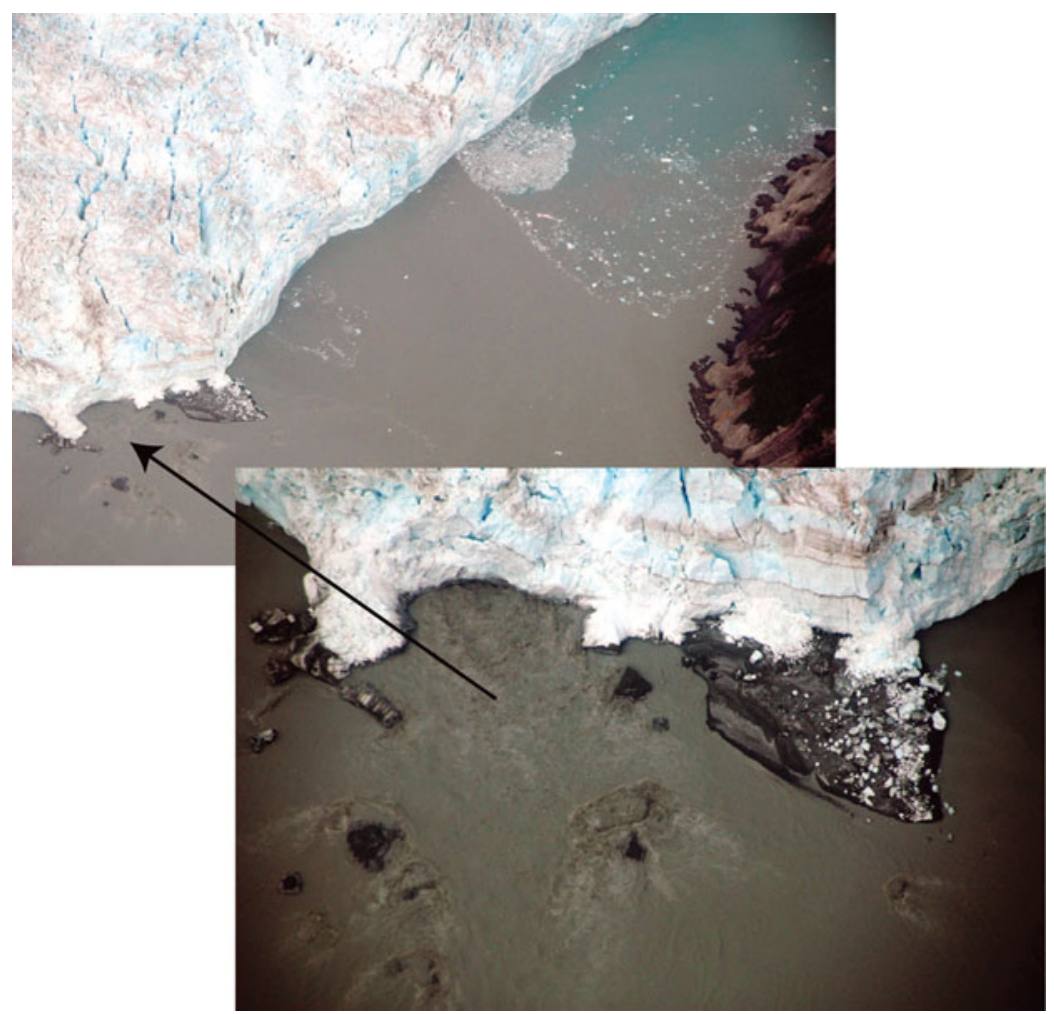

Fig. 1. Glaciofluvial sediments are exposed at the ice face on this photograph taken on 11 August 2007. Subglacial stream discharging from terminus (red arrow) is the likely source of the sediment. (Photo by B. Molnia, US Geological Survey.) 


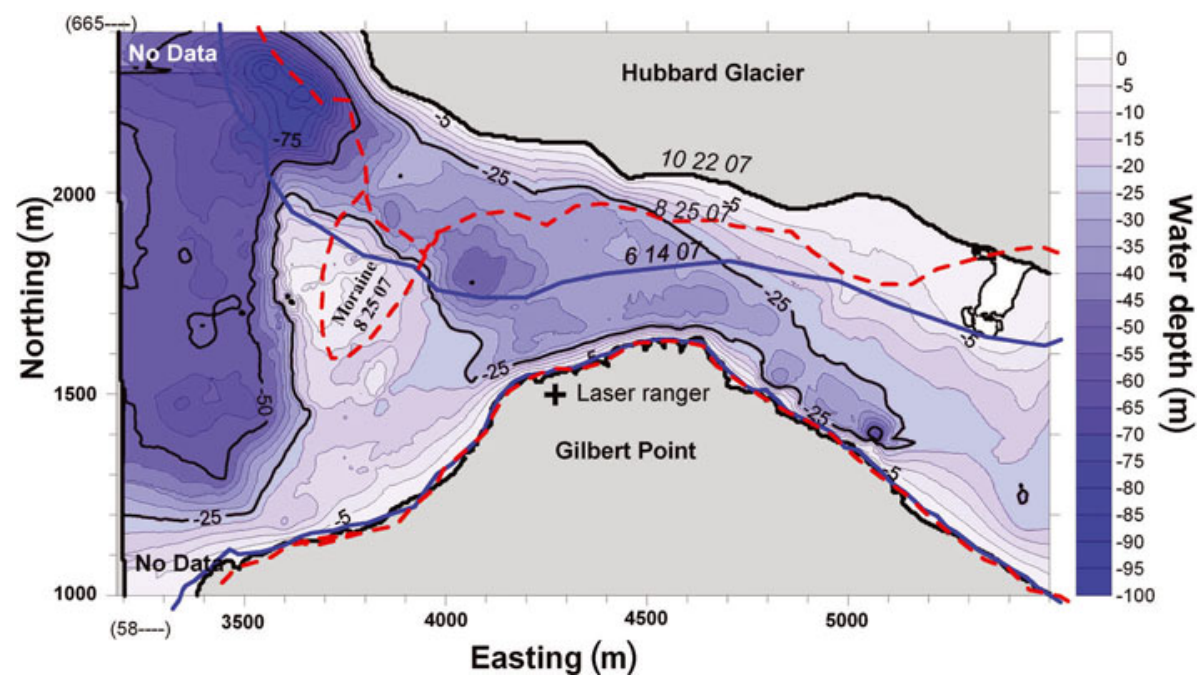

Fig. 2. Bathymetric survey of 22 October 2007 (10 22 07); $5 \mathrm{~m}$ contour interval, Universal Transverse Mercator (UTM) North American Datum 1983 (NAD83) zone 7 (Z7). The glacier terminus outline is from a SAR image taken the same day as the survey. Also shown (in red) are the approximate position of the glacier terminus and the ice-marginal glaciofluvial moraine as resolved from a SAR image taken on 25 August 2007 (8 25 07) and (in blue) the terminus position on 14 June 2007 (6 14 07) when laser range data indicated it was only $120 \mathrm{~m}$ from Gilbert Point. Laser ranger indicated by cross $(+)$.

were still in place when photographed on 31 August, but the fan had not grown and in fact appeared to have diminished in size. SAR and time-lapse images show the deposit gradually shrinking during early September, probably as a result of erosion by tidal currents. Sediments were no longer visible by 15 September, and the ice spur itself disintegrated and was completely gone on or about 19 September.

We conducted a bathymetric survey on 22 October 2007, to assess the volume and extent of the August sedimentation event (Fig. 2). We compared this survey with a US National Oceanic and Atmospheric Administration (NOAA) survey of Disenchantment Bay conducted on 7 September 2006. The NOAA survey was limited to the area west of Gilbert Point because of unsafe conditions within the gap. A 'sill' just west of Gilbert Point is visible in Figure 2 and in all bathymetric surveys since the 2002 outburst flood (Motyka and Truffer, 2007). The mid-June 2007 terminus position slightly overrides this sill (Fig. 2). It was at this location that the subglacial stream discharged and deposited sediments that became exposed in August.

Figure 4 shows an isopach map derived by comparing the 2007 and 2006 bathymetry, with seabed changes relative to the 2006 survey. The isopach map is best defined for the regions where both surveys had good data coverage, which luckily is the center of the map, directly over the sill. The glaciofluvial fan-deposit and terminus positions from $25 \mathrm{Au}$ gust are superimposed onto the map to show their relationship to where submarine sediment accumulated. Interestingly, most of the accumulation occurred on the west side of the sill and is $>30 \mathrm{~m}$ thick in places. This sediment load is perched on the sill over a steep westerly drop-off (cf. Fig. 2). Sediment also accumulated directly on the sill, and some sediment has filled in parts of the channel between Gilbert Point and the terminus. However, the bathymetric data suggest that other parts of the channel have been scoured and deepened. The glacier may have eroded sediments in the gap entrance during its spring advance (Fig. 4). The 14 June terminus position falls directly over the scoured area east of the sill. In addition, the increase in channel floor height just south of this position could reflect sediment shoved forward by ice advance. High tidal currents in the restriction probably eroded the channel to the south of the sill.

From analysis of the isopach map, SAR images and aerial photographs, we estimate the total volume of sediment deposited by the subglacial stream was $\sim 3.3 \times 10^{6} \mathrm{~m}^{3}$, some of which has been subsequently eroded. If we assume that the deposition occurred over a 3 week period (roughly correlating with our imagery), then sediment flux from this stream averaged $\sim 0.16 \times 10^{6} \mathrm{~m}^{3} \mathrm{~d}^{-1}$. This estimate is a minimum because not all sediment was deposited locally. As a comparison, the total terminus-wide glaciofluvial sediment flux for three tidewater glaciers in Glacier Bay, Alaska, was reported to range from $\sim 0.02$ to $0.20 \times 10^{6} \mathrm{~m}^{3} \mathrm{~d}^{-1}$ (Hunter

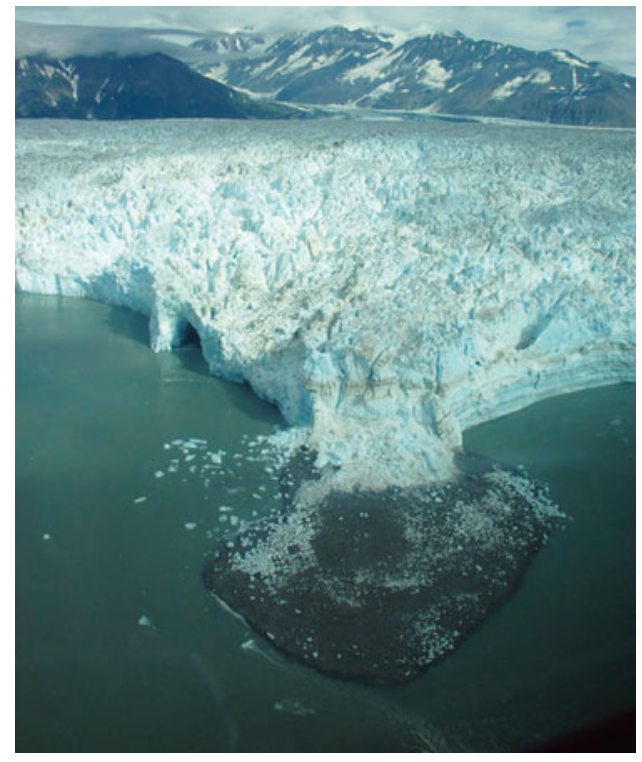

Fig. 3. Apron of ice-marginal accumulated glaciofluvial sediment on 26 August 2007. The main trunk of Hubbard Glacier lies in the background. Gilbert Point lies across from the apron and is under the aircraft. (Aerial photo by A. Arendt, NASA Goddard Space Flight Center.) 


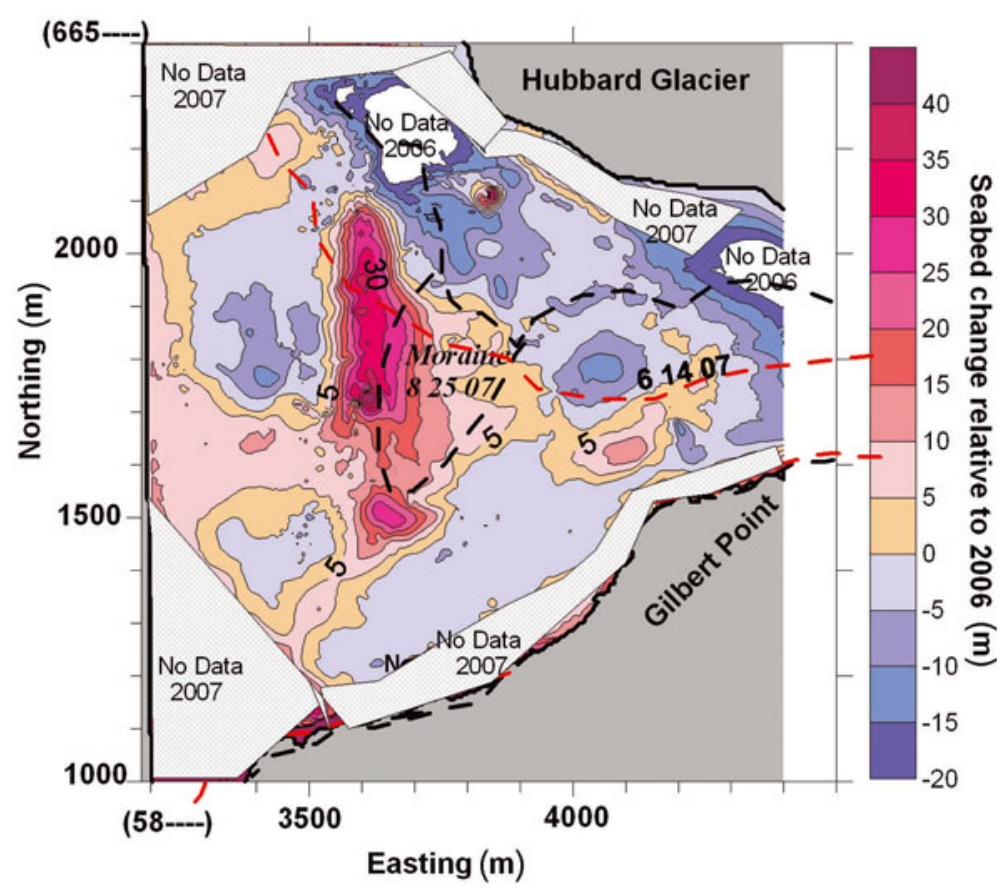

Fig. 4. Isopach map comparing 2007 relative to 2006 bathymetry; $5 \mathrm{~m}$ contour interval, UTM NAD83 Z7. The subaerial glaciofluvial fan and terminus position from 25 August 2007 (8 25 07) are superimposed to show their relationship to where submarine sediment accumulated.

and others, 1996). It is interesting that the localized rapid sedimentation at Gilbert Point did not lead to a closure this past summer. The probable reason is that the summer retreat was already well underway before the subglacial stream appeared and the sediments began accumulating. In addition, the deposit was of limited extent, so calving continued on either side of the ice spur, thereby exposing the spur and apron to increased erosion and wastage by tidal currents. Currents were probably stronger than normal given the seasonally narrowed channel. What is perplexing is why a subglacial stream would discharge over the sill, rather than on either side of it where water was deeper.

What does this accumulation of sediment at Gilbert Point bode for spring 2008? It is difficult to say. The main channel remains relatively deep. The last closure occurred because morainal material was pushed up and onto the sill from the northeast as well as towards Gilbert Point (Motyka and Truffer, 2007). However, if the terminus advances as far as it did in June 2007, then it will likely reactivate any debris remaining on top and surrounding the sill. Some of it may be pushed and 'spill over' into the deep water to the east (Fig. 2), but sediment may also be pushed south into the channel. This would lead to a closure if erosion by tidal currents could not keep up with the sediment flux. Motyka and Truffer (2007) suggested another closure would occur by 2012. However, with the added glaciofluvial sediment from 2007, closure may happen much sooner, perhaps this spring.

\section{ACKNOWLEDGEMENT}

The manuscript was improved by comments from M. Funk and J. Walder.

Geophysical Institute,

Roman MOTYKA

University of Alaska Fairbanks,

903 Koyukuk Drive, Fairbanks, Alaska 99775-7320, USA

E-mail: jfrjm@uas.alaska.edu
US Army Cold Regions Research and Engineering Laboratory,

Daniel LAWSON 72 Lyme Road, Hanover,

New Hampshire 03755-1290, USA

US Army Corps of Engineers,

George KALLI

Alaska District, Anchorage,

Alaska 99506, USA

US Geological Survey,

926A National Center

12201 Sunrise Valley Drive, Reston, Virginia 20192, USA

Cryospheric Sciences Branch,

Code 614.1,

NASA Goddard Space Flight Center,

Greenbelt, Maryland 20771, USA

1 April 2008

\section{REFERENCES}

Finnegan, D.C., D.E. Lawson, G. Hanlon and G. Kalli. 2007. Near realtime monitoring of tidewater glacier advance and retreat: Hubbard Glacier, southeast Alaska. Eos, 88(52), Fall Meet. Suppl., Abstract C41A-0058.

Hunter, L.E., R.D. Powell and D.E. Lawson. 1996. Flux of debris transported by ice at three Alaskan tidewater glaciers. J. Glaciol. 42(140), 123-135.

Motyka, R.J. and M. Truffer. 2007. Hubbard Glacier, Alaska: 2002 closure of Russell Fjord and implications for future dams. J. Geophys. Res., 112(F2), F02004. (10.1029/2006JF000475.)

Ritchie, J.C., C.S. Lingle, R.J. Motyka and M. Truffer. 2008. Seasonal fluctuations in the advance of a tidewater glacier and potential causes: Hubbard Glacier, Alaska, USA. J. Glaciol., 54(186), 401-411.

Trabant, D.C., R.M. Krimmel, K.A. Echelmeyer, S.L. Zirnheld and D.H. Elsberg. 2003. The slow advance of a calving glacier: Hubbard Glacier, Alaska, U.S.A. Ann. Glaciol., 36, 45-50. 